\title{
PENINGKATAN PRODUKTIVITAS PRODUKSI BREM SEBAGAI UPAYA UNTUK MENGANGKAT POTENSI KABUPATEN WONOGIRI
}

\author{
Y.Djoko Suseno ${ }^{1}$ \\ Edi Wibowo ${ }^{2}$ \\ Universitas Slamet Riyadi Surakarta \\ dora.kusumastuti@yahoo.co.id
}

\begin{abstract}
Tengar Village Nguntonadi sub-district is one of brem-producing centers in Wonogiri region with high quality. However, in the management of brem production many experience barriers in addition to technology and marketing problems. The purpose of this community service activity is to transfer technology to improve the quality of brem production, and marketing management training to increase brem sales value. The method used is through training, mentoring to partners and monitoring although community service activities have been completed to maintain the sustainability of the program. The impact of community service activities is that there has been a transfer of technology from traditional to modern so that brem making becomes more hygienic and quality, as well as changes in marketing patterns from direct sales to sales through social media.
\end{abstract}

Key words : Wonogiri's brem, technology, marketing.

\section{Pendahuluan}

Brem adalah makanan ringan yang biasa dikonsumsi oleh masyarakat Indonesia. Kue Brem mengandung energi sebesar 249 kilokalori, protein 3,4 gram, karbohidrat 58 gram, lemak 0,4 gram, kalsium 196 miligram, fosfor 86 miligram, dan zat besi 2 miligram. Selain itu di dalam Kue Brem juga terkandung vitamin A sebanyak 0 IU, vitamin B1 0,34 miligram dan vitamin C 0 miligram. Hasil tersebut didapat dari melakukan penelitian terhadap 100 gram Kue Brem, dengan jumlah yang dapat dimakan sebanyak $100 \%$.

Tabel.1. Kandungan Nilai Gizi Brem

\begin{tabular}{|l|l|}
\hline Kandungan & Kal \\
\hline Energi Kue Brem & $249 \mathrm{kkal}$ \\
\hline Protein Kue Brem & $3,4 \mathrm{gr}$ \\
\hline Lemak Kue Brem & $0,4 \mathrm{gr}$ \\
\hline Karbohidrat Kue Brem & $58 \mathrm{gr}$ \\
\hline Kalsium Kue Brem & $196 \mathrm{mg}$ \\
\hline Fosfor Kue Brem & $86 \mathrm{mg}$ \\
\hline Zat Besi Kue Brem & $2 \mathrm{mg}$ \\
\hline Vitamin A Kue Brem & $0 \mathrm{IU}$ \\
\hline Vitamin B1 Kue Brem & $0,34 \mathrm{mg}$ \\
\hline Vitamin C Kue Brem & $0,34 \mathrm{mg}$ \\
\hline
\end{tabular}

Brem dibuat dengan mengandalkan proses fermentasi. Brem dibuat dari ketan. Proses fermentasi akan dibantu dengan sebuah ragi yang dibuat dengan bantuan kapang atau mikroorganisme

\footnotetext{
${ }^{1}$ Dr.Y.Djoko Suseno.SE.Msi Dosen Fakultas Ekonomi Universitas Slamet Riyadi Surakarta

${ }^{2}$ Edi Wibowo.SE.MM Dosen Fakultas Ekonomi Universitas Slamet Riyadi Surakarta
} 
pengurai. Proses fermentasi brem akan dimulai dengan penghancuran pati yang ditemukan dalam ketan hitam dan ketan putih menjadi gula yang lebih sederhan.

Gula yang dibentuk menjadi lebih sederhana kemudian akan dibentuk menjadi alkohol yang kemudian berubah menjadi zat asam. Proses ini memanfaatkan Acetobacter dan Pediococcus. Kemudian setelah proses ini selesai maka asam yang sudah terbentuk akan dirubah menjadi cita rasa yang muncul pada brem. Zat kimia yang terbentuk dalam proses ini adalah asam piruvat dan asam laktat. Sementara itu zat yang terbentuk dalam brem adalah seperti pati dan gula.

Berikut ini adalah beberapa manfaat makan brem dapat bermanfaat meningkatkan kadar hormon. Brem mengandung alkohol yang bila dimakan tidak berlebihan maka akan membantu meningkatkan fungsi arteri darah. Arteri darah akan menyebabkan aliran darah menjadi lancar dan mendukung pekerjaan enzim dan produksi hormon sehinggga membuat metabolisme tubuh menjadi lebih baik.

Brem juga bisa mengurangi resiko terkena penyakit jantung dan stroke. Hal ini disebabkan karena alkohol yang terkandung dalam brem bisa membuat aliran darah pada pembuluh darah menjadi lebih lancar. Brem akan menghilangkan timbunan lemak dan plak pada pembuluh darah. Baik juga unutk jantung dan stroke.

Brem juga bisa mengurangi kadar asam dalam darah dan mencegah pembekuan darah. Masalah ini biasanya sering muncul pada orang tua . Brem bisa meningkatkan produksi dehidro epiandrosteron yang ternyata sangat baik untuk melancarakan peredaran darah.

Brem dapat mengurangi kadar kolesterol buruk yang bisa menyebabkan tingginya kadar kolesterol dalam darah dan meningkatkan beberapa resiko penyakit seperti jantung, diabetes dan stroke. Baik juga untuk mengurangi kadar kolesterol. Brem juga bisa meningkatkan kesehatan kulit. Konsumsi brem dalam jumlah yang wajar bisa membuat proses regenerasi sel kulit mati berjalan lebih cepat sehingga produksi sel - sel kulit yang sehat akan mudah terbentuk.

Konsumsi brem yang wajar juga bisa menurunkan resiko jerawat dan mengurangi jerawat. Hal ini disebabkan karena brem bisa meningkatkan hormon reproduksi pada remaja yang biasanya menyebabkan jerawat. Brem bisa menjadi sumber tenaga karena mengandung gula yang manis. Saat tubuh Anda terasa lemah dan kurang berdaya maka sepotong brem akan membuat tenaga anda menjadi pulih kembali.

Kabupaten Wonogiri, dengan luas wilayah 182.236,02 Ha dengan batas-batas Sebelah Utara : berbatas dengan Kabupaten Sukoharjo dan Kabupaten Karanganyar, Sebelah Timur : berbatas dengan Kabupaten Karanganyar dan Kabupaten Ponorogo (Jawa Timur),Sebelah Selatan : berbatas dengan Kabupaten Pacitan (Jawa Timir) dan Samudra Indonesia, Sebelah Barat : berbatas dengan Daerah Istimewa Yogyakarta dan Kabupaten Klaten.

Dengan topografi daerah yang tidak rata, perbedaan antara satu kawasan dengan kawasan lain membuat kondisi sumber daya alam juga saling berbeda. Di Wonogiri hampir sebagian besar tanahnya tidak terlalu subur untuk pertanian, berbatuan dan kering membuat penduduknya lebih banyak merantau(boro) ke kota besar di Indonesia dan bekerja pada sektor non formal.

Desa Gebang Kecamatan Nguntoronadi adalah sebuah Desa yang terdiri atas 7 (tujuh) dusun dan di sebelah selatan dan barat Waduk Gajah Mungkur (WGM), merupakan daerah penghasil makanan Brem. Ada sekitar 3 (tiga) dusun yang hampir sebanyak kurang lebih 80 $\%$ dari warga di dusun tersebut sebagai penghasil brem yaitu Dusun Tenggar Lor, Tenggar Kidul dan Tanjung (Suharsih, 2010). Sehingga bisa dipastikan bahwa Makanan Brem merupakan produk unggulan daerah tersebut. Usaha sektor ini sudah menyebar ke daerah pemasaran meliputi daerah Solo Raya yaitu Surakarta, Boyolali, Karanganyar, Sragen, Sukoharjo dan Wonogiri. Desa Gebang merupakan sentra penghasil brem yang yang sangat berkualitas. Potensi industri makanan brem Desa Tenger merupakan industri rumahan yang dihasilkan oleh penduduk desa tersebut sebagai pekerjaan sampingan selain bertani.

Produksi brem Desa Tenger memiliki keunggulan jika dibandingkan dengan brem yang dihasilkan oleh daerah Madiun, yaitu brem produksi desa Tengger hanya dibuat dengan mengunakan sari tape saja, tanpa memasukan ampas dari ketannya. Bila dibandingkan 
dengan eksistensi brem padat di Madiun cukup jauh yaitu brem sudah melekat menjadi oleholeh dari Madiun. Selain itu kapasitas produksi rata-rata dari Brem dari Desa Tengger hanya berkapasitas 100-200kg/hari sedangkan Brem Madiun mampu menghasilkan sekitar 600 $1000 \mathrm{~kg} /$ hari. Harga jual Brem Wonogiri dari masing-masing produk adalah Rp. $25.000,00 / \mathrm{kg}$ jauh dibawah brem madiun yang mencapai Rp. $120.000,00 / \mathrm{kg}$.

Potensi dari produksi brem Desa Tengger perlu mendapatkan dukungan dan pendampingan supaya dapat meningkatkan hasil produksi brem yang akan berdampak pada peningkatan kesejahteraan masyarakat, dan dapat menciptakan peluang kerja baru bagi masyarakat desa sehingga dapat menekan anggka boro atau perantauan tenaga kerja ke kota besar.

Kegiatan tim pengabdian masyarakat ini adalah(1) meningkatkan proses produksi pembuatan brem agar lebih produktif dan efektif dan (2) meningkatkan kualitas manajemen UKM dan strategi pemasaran produksi yang masih konvensional menjadi lebih modern.

\section{Masalah}

Permasalahan yang dihadapi oleh mitra adalah masih tradisionalnya proses teknologi yang digunakan dalam memproduksi brem, diantaranya adalah mesin pemeras sari tape masih bersifat manual, sehingga hasil sari tape ketan tidak benar dapat keluar sarinya, dan alat penjemur hasil sari tape terbuat dari bambu sehingga brem mudah pecah dan juga kadar kebersihannya kurang karena bambu relatif mudah terserang jamur kayu.

Permasalahan selanjutnya adalah proses managemen pembukuan dan pemasaran masih cenderung konvensional. Dari permasalah ini diperlukan suatu pelatihan managemen pembukuan dan pemasaran agar dapat meningkatkan produktifitas hasil brem.

\section{Metode}

a. Metode Pelaksanaan Kegiatan Masyarakat

Program Kemitraan Masyarakat (PKM) terhadap UKM Brem di Tanjung, Gebang, Kec. Nguntorona di Kab. Wonogiri adalah berupaya untuk meningkatkan kualitas dan kuantitas produksi brem melalui optimalisasi mesin pemerasan sari tape dan alat cetakan pembuatan brem, serta pelatihan pembuatan laporan keuangan dan pemasaran. Berdasarkan rincian operasional program tersebut diharapkan:

1. Akan tampak volume pekerjaan/ kegiatan produksi.

2. Ada evaluasi kegiatan

3. Ada evaluasi kinerja mitra

4.Keberlanjutan dari program kemitraan masyarakat akan tetap ada keberlanjutan dengan pihak manapun.

Metode yang digunakan dalam kegiatan pengabdian masyarakat ini adalah melalui penyuluhan dan pendampingan terhadap UKM Mitra. Penyluhan berupa kegiatan sosialisasi dan pendampingan berupa kegiatan pelatihan sampai pada action dari UKM mitra sampai berhasil meningkatkan kualitas dan kuantitas produksi brem.

b. Teknik Pengumpulan dan Analisis Data

Teknik analisis data yang digunakan adalah melalui pengamatan, FGD,observasi, wawancara dan dokumantasi.Teknik observasi dilakukan untuk memperoleh data yang utuh mengenai kendala produksi brem.

c. Lokasi, Waktu dan Durasi Kegiatan

Lokasi pengabdian masyarakat berada di Desa Tengger, Kecamatan Nguntoronadi Kabupaten Wonogiri. Waktu kegiatan pengabdian pada masyarakat adalah 8 bulan, dengan durasi sesuai waktu yang ditentukan. 


\section{Hasil dan Pembahasan}

Undang-Undang Nomor 3 Tahun 2014 tentang Perindustrian mendefinisikan pengertian Industri adalah seluruh bentuk dari kegiatan ekonomi yang mengelolah bahan baku dan atau memanfaatkan sumber daya industri, sehingga dapat menghasilkan barang yang memiliki nilai tambah atau manfaat yang lebih tinggi, termasuk juga jasa industri. Industri kecil didefinisikan adalah indurti yang memiliki cash flow kurang dari 1 milyard tidak termasuk investasi tanah dan bangunan serta memiliki karyawan kurang dari 20 orang.

Perkembangan industri kecil menengah memiliki peran yang sangat besar bagi perkembangan industri nasional, diantaranya adalah mampu menyerap tenaga kerja, meningkatkan penghasilan masyarakat dan mampu menahan ekonomi negara dari terpaan krisis ekonomi(Dora Kususmastuti \& Sutoyo :2017).

Pemberdayaan masyarakat merupakan konsep yang berasal dari kata 'daya' (power). Sedangkan pemberdayaan berasal dari kata 'empower' dimana dalam Merriam Webster dan Oxford English Dictionary menyatakan bahwa power mempunyai dua arti. Pertama,power berarti to give power or authority yang berarti 'memberikan kekuasaan, mengalihkan kekuasaan atau mendelegasikan otoritas ke pihak lain'. Pengertian kedua adalah 'to give ability or to enable' yang bisa diartikan sebagai usaha untuk memberikan kemampuan atau pemberdayaan (Rosida Sari: 2016).

Potensi Desa Tengar Kecamatan Nguntoronadi adalah bertumbuhnya indutri kecil penghasil brem, yang dalam perkebangannya dapat disebut sebagai sentra industri brem di Kabupaten Wonogiri. Dengan bertumbuhnya sentra industri brem ini diharapkan mampu meningkatkan kesejahteraan masyarakat desa setempat dan mampu menekan angka urbanisasi"boro" ke kota-kota besar di Indonesia.

Kerangka besar pengabdian masyarakat ini adalah memberdayakan pelaku industri kecil menengah untuk dapat meningkatkan kualitas dan kwantitas hasil produksi brem Desa Tenggaran dan mampu membuat branding bahwa Kecamatan Nguntoronadi merupakan sentra industri brem yang mampu duduk sejajar dengan sentra industri brem Kabupaten Madiun.

\section{Kegiatan Pertama: Peningkatan Hasil Produksi Brem Melalui Teknologi Tetap Guna}

Bentuk brem ada beberapa yang dikenal di pasaran, berupa makanan dan minuman. Brem berupa makanan terkenal brem Madiun dari Madiun yang telah menjadi oleh-oleh khas Madiun dan brem Wonogiri dari Wonogiri, sedangkan yang berupa cairan berasal dari pulau Bali dikenal dengan nama brem Bali dan Nusa Tenggara Barat dikenal dengan nama brem Lombok NTB.

Bentuk pertama yang lebih dulu dikenal adalah makanan tradisional khas yang berasal dari kecamatan Caruban, Kabupaten Madiun, dan berasal dari dua desa penghasil: Bancong dan Kaliabu. Brem dikemas berbentuk lempengan agak kekuningan, rata-rata berukuran kurang lebih $15 \mathrm{~cm}$ x $5 \mathrm{~cm}$ x $0,5 \mathrm{~cm}$. Untuk lebih memaksimalkan pemasarannya, brem kini dikemas dalam bentuk kecil kecil seukuran permen, sehingga mudah untuk dikantongi. Biasanya pada sekitar tahun 80 -an, brem dalam bentuk ini dijual asongan oleh para pedagang di sekitar stasiun-stasiun di kereta api di daerah Jawa Timur.

Brem bentuk kedua berasal dari Wonogiri, Jawa Tengah, berbentuk lempeng pipih bundar dengan diameter rata-rata $5 \mathrm{~cm}$ dan ketebalan sekitar $0,3 \mathrm{~cm}$. Brem asal Wonogiri berwarna putih dan proses pengeringannya melalui dijemur langsung dibawah panas terik matahari selama tiga hari sehingga teksturnya kering renyah dan garing.

Selain itu ada juga Brem yang berbentuk cair berasal dari Bali dan Nusa Tenggara, brem asal bali berwarna putih seperti susu sedangkan yang berasal dari Nusa Tenggara berwarna merah. Cara Pembuatan Brem Padat:

1. Cuci beras ketan sampai bersih kemudian rendam sebentar.

2. Angkat kemudian kukus kurang lebih 1 jam.

3. Setelah itu, difermentasikan atau proses peragian dengan menambahkan ragi tape kemudian didiamkan selama 7 hari.

4. Selanjutnya, proses pengepresan untuk mendapat sari yang dihasilkan ketan yang telah difermentasi. 
5. Rebus sari ketan dan aduk sampai mengental. Kemudian masukkan adonan ke dalam mesin pengaduk dan ditambahkan soda kue secukupnya.

6. Selanjutnya sari tape ketan keluarkan dan dicetak pada cetakan bulat

7. Selanjutnya brem dijemur dengan mengunakan sinar matahari sampai kering.

8. Brem siap untuk dinikmati atau siap dijual untuk usaha dikemas dengan plastik tebal di press.

Proses pembuatan brem selama ini masih mengunakan teknologi manual, yaitu pada tahap keempat proses pengepresan. Dalam proses ini masih mengunakan mesin yang manual sehingga hasil kurang maksimal yaitu sari tape tidak bisa keluar semuanya.

Kendala selanjutnya adalah alat yang digunakan untuk menjemur brem selama ini terbuat dari bambu, setelah diapai berulangkali akan menjamur dan brem mudah pecah karena tipis dan rapuh. Ini tentu saja akan berdampak terhadap hasil dari kualitas brem itu sendiri.

Setelah mengunakan alat pengpres sari tape yang terbuat dengan teknologi listrik, hasil sari tape dapat maksimal. Selanjutnya untuk alat penjemur brem yang terbuat dari acrilc memiliki keunggulan selain lebih sehat dan bersih karena tidak rawan terhadap jamur, alat ini juga memiliki keunggulan mampu menghasilkan brem yang lebih tebal dan tidak mudah pecah.

\section{Kegiatan Kedua: Peningkatan Kualitas Brem Melalui Varian Rasa Brem Yang Beranekarasa}

Produk brem padat selama ini belum mengalami perkembangan yang berarti, baik dari rasa, bentuk maupun kemasan, sehingga pengembangan produk brem padat dirasakan perlu. Pengembangan produk brem padat dapat dilakukan dengan membuat brem padat aneka rasa, apalagi pengembangan produk pangan berbagai rasa saat ini sedang menjadi trend. Pembuatan brem padat aneka rasa dapat dilakukan dengan menambahkan flavor buah dan pewarna makanan. Diharapkan brem padat aneka rasa ini dapat memberikan alternatif pilihan kepada konsumen yang kurang menyukai rasa brem padat yang berasa sedikit asam dan terasa alkoholnya.

Umumnya brem yang diproduksi oleh industri kecil menegah desa tengaran baru mampu menghasilkan brem dengan rasa original. Pelaku industri brem disini belum mampu menciptakan varian rassa yang beranekaragam dan memenuhi selera pasar.

Pada proses pemberian cita rassa dan pewarna dapat dilakukan melalui proses sebagai berikut: Beras ketan putih kualitas super dicuci dan direndam kurang lebih 4-6 jam. Setelah itu, dicuci bersih, ditiriskan, lalu ditanak dengan menggunakan kukusan selama $1 \mathrm{jam}$. Setelah proses pengukusan, beras ketan putih ini masuk ke dalam proses peragian atau fregmentasi selama kurang lebih 7 hari. Setelah 7 hari, ketan putih yang sudah terfregmentasi diambil lalu di pres dengan alat khusus untuk mendapatkan air sari tape. Nah, air ini kemudian direbus lagi, dan di mixer sambil dicampur dengan perasa. Setelah selesai masuk langkah terakhir, yaitu pengecoran di tempat khusus dan dijemur."

Tujuan pemberian pewarna pada makanan untuk memperbaiki penampilan makanan agar lebih menarik perhatian. Di Indonesia telah dikenal banyak pewarna alami, contohnya daun suji dan daun pandan (warna hijau), kunyit (warna kuning), warna telang (warna biru keunguan), gula kelapa (warna merah kecoklatan), cabe dan bunga belimbing sayur (warna merah). Pewarna alami ini sangat aman bagi kesehatan manusia. tetapi, pengetahuannya kurang maksimal karena masih terdapat rasa atau aroma yang bisa mengganggu rasa atau aroma makanan aslinya.

Untuk mengatasi masalah tersebut, telah banyak diproduksi pewarna makanan sintesis. Contohnya: sunset yellow FCF (warna oranye), violet GB (warna ungu), tartrazine (warna kuning), indigo carmine (warna biru). Tetapi, harga pewarna makanan sintesis tersebut relatif mahal, sehingga ada orang yang tidak bertanggung jawab yang menggantinya dengan pewarna tekstil dengan harga yang murah namun berbahaya bagi kesehatan. Pewarna tekstil yang sering disalahgunakan sebagai pewarna makanan, yaitu rhodamine B (warna merah) dan metanil yellow (warna kuning). Bahanbahan tersebut dapat memicu terjadinya kanker.

Adapun pewarna makanan dan perasa makanan yang aman adalah yang bersal dari berasal dari golongan ester. Contoh: Isoamil asetat (rasa pisang), isoamil valerat (rasa apel), butil butirat (rasa nanas), isobutil propionat (rasa rum), butyl butirate yang memiliki rasa mirip pir dan nanas.

Dalam pembuatan aneka rasa varian brem komposisi yang dibutuhkan adalah satu sendok makan setiap kg bahan brem baik perasa maupun pewarna makanan. Pewarna makanan ditambahkan 
menyesuaikan dari perisa makanan yang digunakan. Apabila yang digunakan perisa durian maka pewarna makanan yang dibutuhkan adalah warna kuning.

\section{Kegiatan Ketiga: PelatihanPemasaran}

Menurut Tjiptono ${ }^{3}$ (2007), tujuan utama dari promosi adalah menginformasikan, membujuk serta mengingatkan pelanggan sasaran tentang perusahaan dan produk atau jasa yang dihasilkan. Bisa diartikan bahwa tujuan dalam kegiatan promosi yang dilakukan oleh penjual (seller) adalah untuk memberikan informasi serta membujuk pembeli (buyer) agar sadar dan ingat akan produk atau jasa yang ditawarkan oleh penjual. Dalam melakukan kegiatan promosi oleh penjual (seller) maka dibutuhkan media atau alat-alat yang dapat menunjang kegiatan tersebut.

Menurut Kotler (1998) dalam melaksanakan kegiatan pemasaran, perusahaan menggunakan alat-alat promosi yang terdiri dari lima macam sebagai berikut. Periklanan (advertising) Periklanan menurut Kotler didefinisikan sebagai berikut :

a.Periklanan merupakan segala bentuk penyajian dan promosi atas ide-ide, barang ataupun jasa yang mendapat imbalan dan tidak bersifat pribadi, oleh sponsor yang telah diidentifikasikan.

b.Promosi penjualan (sales promotion)Promosi penjualan menurut Kotler didefinisikan sebagai berikut: promosi penjualan terdiri dari kumpulan kiat-kiat insentive yang beragam, yang kebanyakan berjangka pendek, dirancang untuk mendorong pembelian suatu produk atau jasa tertentu secara lebih cepat atau lebih besar oleh konsumen atau pedagang. c.Hubungan masyarakat dan publisitas (public relation and publicity)Kotler mendefinisikan hubungan masyarakat dan publisitas sebagai berikut: hubungan masyarakat dan publisitas adalah suatu program yang dirancang secara beragam untuk mempromosikan dan menjaga kesan perusahaan ataupun produk sendiri.

d.Penjualan personal (personal selling)Kotler mendefinisikan penjualan personal sebagai berikut: penjualan personal adalah interaksi tatap muka dengan jalan membuat presentasi, menjawab pertanyaan dan mendapatkan order.

e.Pemasaran langsung (direct marketing)Kotler mendefinisikan pemasaran langsung sebagai berikut: pemasaran langsung adalah suatu bentuk dari alat-alat promosi yang menggunakan pesawat telepon, fax, e-mail atau internet untuk berkomunikasi secara langsung atau mendapat tanggapan langsung dari konsumen.

Teknologi informasi telah menjadi pendukung utama untuk memperoleh informasi dengan sangat cepat dan mudah. Melalui media ini mereka dapat memperoleh dan menyampaikan berbagai informasi yang dibutuhkan kapan dan dimana saja. Jejaring sosial networking sudah semakin maju yang saat ini bisa dikatakan sebagai yang fenomenal adalah twitter dan facebook. dunia maya juga mampu dimanfaatkan untuk membuat seseorang tidak hanya bisa duduk diam tanpa penghasilan, namun dengan internet mereka mampu mendapatkan penghasilan.

Berkembangnya internet banyak hal baru yang timbul dari berkembangnya internet tersebut salah satunya adalah pembelian atau belanja barang ataupun jasa secara online. Internet saat ini dirasa bisa menjadi solusi pemasaran yang sangat bagus karena bisa diakses oleh orang dalam waktu yang tanpa batas dan bisa diakses oleh orang lain darimana saja berada. Pemasaran media online dapat dikatakan sebagai bisnis yang menjanjikan untuk saat ini.

Strategi pemasaran adalah pengambilan keputusan-keputusan dalam hubungan tentang biaya pemasaran, bauran pemasaran, alokasi pemasaran dengan keadaan lingkungan yang diharapkan dan kondisi pesaing Online marketing adalah segala usaha yang dilakukan untuk melakukan pemasaran suatu produk atau jasa melalui atau menggunakan media internet. Internet merupakan salah satu penemuan mutakhir era globalisasi di bidang teknologi informasi yang sangat menguntungkan semua manusia di seluruh dunia untuk berbagi informasi dan berkomunikasi, termasuk berbagi informasi produk atau jasa yang dijual.

Selama ini proses pemasaaran brem dilakukan dalam bentuk curah dan dijual secara kiloan terhadap pedagang oleh-oleh yang di Surakarta. Pembeli dalam hal ini melakukan pengemasan dan

${ }^{3}$ Fandy Tjiptono“Strategi Pemasaran”,Edisi 5,Andi, Yogyakarta, 2007 
pemberian merk brem wonogiri tersebut. Secara umum hal ini akan berakibat adanya ketergantungan dari para pembuat brem Desa Tengar terhadap para tengkulak.

Dalam kegiatan pengabdian masyarakat Desa Tengar Nguntoronadi ini, dilaksanakan kegiatan pelatihan strategi pemasaran mengunakan media internet yaitu mengunakan media sosial. Media sosial yang digunakan adalah mengunakan face book, twiter maupun path. Memang tidak bisa dipungkiri bahwa penguasaan pengunaan teknologi sulit bagi para pelaku pembuat brem, akan tetapi dalam hal ini anak-anak dari pembuat brem dapat dilibatkan untuk mengelola pemasaran melalui sosial media.

Dengan kegiatan pengabdian masyarakat ini diharapkan para pembuat brem Desa Tengar ini dapat langsung memasarkan produksi brem dengan mengemas dalam kemasan yang baik serta mampu menjual sendiri brem tersebut diharapkan akan dapat meningkatkan penghasilan dari mitra.

\section{Simpulan}

Tingkat ketercapaian dari pengabdian masyarakat ini adalah dapat meningkatkan produktifitas pembuatan brem serta meningkatnya kualitas dan kebersihan brem dan dapat meningkatkan kesejahteraan mitra. Terjadinya peningkatan produktifitas produksi brem tersebut melalui adanya upaya alih teknologi, palatihan manageman pemasaran melalui olahan variasi rasa brem, dan pemasaran brem sosial media.

Kegiatan pengabdian masyarakat ini merupakan bagian kecil dari upaya untuk dapat memajukan industri kecil. Diharapkan peran dari pemerintah secara bertahap melalui dinas perindustria, dinas koperasi dan usaha kecil, serta dinas-dinas terkait untuk senantiasa melakukan pendampingan terhadap industri kecil agar tetap dapat eksis dan berkembang.

\section{Daftar Pustaka}

Anonymous. 2003. Madiun. http://www.madiun.go.id. Tanggal akses 20 Maret 2004. Ariyanto, G. 2003. Brem Khas tapi Berkendala. Kompas edisi Selasa 18 Maret.

Darsono, Suhadi. 1977. Ilmu Bahan Listrik I. Jakarta :

Dora Kusumastuti\& Sutoyo. 2017. Legal Protektion Of Small and Medium Industries in dealing With Global Clallenges. ICTESS. UNISRI

Rora Karya Daryanto. 2004. Pengetahuan Teknik Elektronika. Jakarta : Bumi Aksara

Harten, Van. 1983. Instilasi Listrik Arus Kuat 2. Jakarta : Bina Cipta

Kertiase, Nyoman. 1997. Fisika I. Jakarta : Balai Pustaka

Kurmi, Gupta, 1986. Mechine Design Theory and Practice, India. Loudon, G. Schiffman., 2004, Consumer Behavior, 8th Edition, Pearson Education International, New Jersey. Niemman, Gustav, 1978. Mechine Element, Volume 1, Springer Verlag, German.

Porter, Michael., 1985, Competitive Advantage: The Free Press., A Division Millan Inc., New York. Rosnida Sari . Meneropong usaha penginapan masyarakat Lokal dan Manca Negara di Desa Mon

Ikeun Lhoknga) Jurnal Al-Bayan / VOL. 22 NO. 34 JULI - DESEMBER 2016

Fandy Tjiptono"Strategi Pemasaran",Edisi 5,Andi, Yogyakarta, 2007

Philip Kotler,"Manajemen Pemasaran”,jilid 2,Edisi Bahasa Indonesia,Prentice Hall, New Jersey, 1998 